\title{
Representations of people living with HIV: influences on the late diagnosis of infection*
}

\author{
Representações de pessoas vivendo com hiv: influxos sobre o diagnóstico tardio da infecção \\ Representaciones de personas viviendo con vih: influjos \\ acerca del diagnóstico tardío de la infección
}

How to cite this article:

Ribeiro LCS, Giami A, Freitas MIF. Representations of people living with HIV: influences on the late diagnosis of infection. Rev Esc Enferm USP. 2019;53:e03439. DOI: http://dx.doi.org/10.1590/S1980-220X2018009703439

\section{Luana Carla Santana Ribeiro ${ }^{1}$ \\ Alain Giami² \\ Maria Imaculada de Fátima Freitas ${ }^{1}$ \\ * Extracted from the thesis: "Diagnóstico tardio de infecção pelo HIV: magnitude do fenômeno e trajetórias de pessoas que vivem com HIV", Programa de Pós-Graduação em Enfermagem, Universidade Federal de Minas Gerais, 2018. \\ 1 Universidade Federal de Minas \\ Gerais, Programa de Pós-Graduação em Enfermagem, Belo Horizonte, MG, Brazil \\ ${ }^{2}$ Université de Paris Saclay, Paris, France.}

\begin{abstract}
Objective: To analyze the representations constructed by people living with HIV on the infection and their influence on the late search for diagnosis. Method: A qualitative study, conducted through an open interview with people who had a late diagnosis of HIV infection. The theoretical framework adopted was the Theory of Social Representations based on a critical approach. For data analysis, was used the Structural Analysis of Narration method and the MAXQDA $12^{\oplus}$ software. Results: Eighteen people participated in the study. The following original representations were unveiled: AIDS as a transmissible and dangerous disease; disease of the other; severe, incurable and deadly disease; and denial of risk due to trust in a steady partner. These representations contributed to the late search for diagnosis, either because of the attitude of distance from susceptible people, or because they did not perceive or deny the risks to which they were exposed in their life trajectories. Conclusion: Understanding the reasons that lead people to a late diagnosis of HIV is imperative in the current epidemic scenario for the planning and implementation of new strategies and policies for the timely diagnosis of the infection.
\end{abstract}

\section{DESCRIPTORS}

HIV; Acquired Immunodeficiency Syndrome; Delayed Diagnosis; Public Health Nursing. 


\section{INTRODUCTION}

HIV/AIDS has permeated the collective imagination from the first cases in the early 1980s. Since it became a worldwide epidemic, people in their different sociocultural and life contexts construct their representations about the phenomenon and attribute meanings to this problem.

In recent years, research in several countries around the world has highlighted the problem of late diagnosis (LD) of HIV infection with high prevalence rates. This is one of the main obstacles to pandemic control and has serious repercussions for populations, highlighting the increase of infection spread, of morbidity and mortality of people living with HIV (PLHIV) and the decrease in the quality of life of those affected ${ }^{(1-4)}$.

In the HIV diagnosis, is monitored the proportion of PLHIV without treatment who arrive at the health service with immunological impairments that are measured by the value of CD4 T lymphocytes + (LT-CD4+). In 2015, in Brazil, $42 \%$ of PLHIV sought health services late, when they had already developed the syndrome, i.e., with a LT-CD4+ value of less than 350 cells $/ \mathrm{mm}^{3(5)}$.

In studies focused on objective explanations of the problem, were found factors associated with delayed diagnosis of HIV infection, such as older age ${ }^{(3)}$, male sex ${ }^{(6)}$, heterosexuality $^{(7)}$, black race ${ }^{(8)}$, unemployed or low-income people ${ }^{(4)}$. However, people's subjective aspects influencing this phenomenon are still poorly studied.

Several macro and micro determinant factors are related to the problem of HIV infection, highlighting poverty, violence, low schooling, gender inequity and barriers to access of health services. In the field of subjectivity, the following factors stand out: the set of social representations on AIDS, micro-modelling of the AIDS imaginary in feelings of anguish and fear of the proximity of the unknown, difficulties to de-crystallize territories and ideologies already established, the fatalistic conception of the disease, stigma and the plurality of perceptions about HIV infection and prevention ${ }^{(9-10)}$.

In this sense, the ways of thinking and acting in relation to the risks of becoming infected by HIV and in relation to the disease and the infection itself (among other representations composing this object) are determinants in the path to discover the situation of the seropositive individual or with AIDS. The main question of the present study concerns the influence of representations in the life paths of HIV positive people in their search for diagnosis.

The objective of this study was to analyze the representations built by people living with HIV on the infection and their influence on the delayed search by diagnosis.

\section{METHOD}

\section{TYPE OF STUDY}

This is a cut of the qualitative axis of a mixed method study based on the constructivist approaches of sociology, in which the Theory of Social Representations from a critical approach was adopted as theoretical-methodological reference $^{(11)}$. This approach questions the reduction of representations to the process of transformation of a scientific theory into knowledge of common sense as a research par$\operatorname{adigm}^{(12)}$.It also considers that science is not the only determinant in the process, because the sources of representation in social life are varied, and their exclusive function is not defining conducts of a group and creating identity of belonging to it ${ }^{(12)}$, since they also unveil the non-belonging, such as groups of vulnerability to HIV, and include intrapsychic, intraindividual and interindividual functions ${ }^{(11)}$.

The conception of representations of this approach ${ }^{(11)}$ lies at the intersection between the cognitive basis of Flament ${ }^{(13)}$ and the psychoanalytic conception of Kaës ${ }^{(14)}$. According to Flament's conception, representations are revealed individually and collectively and structured around a deep core observed through representations called originals, which are the oldest and last through a variety of life-long experiences as an identity. Around the deep core are peripheral representations more related to everyday life, and more easily modified by disagreements with reality in a process of learning and knowledge ${ }^{(13)}$. The psychoanalytic conception of Kaës states that the existence, constitution and persistence of representations are directly dependent on the trajectory of life backed up by individuals' psychic process from the imagetic nucleus of the object, and also express the ghosts of individuals and provoke resistances ${ }^{(14)}$.

\section{SCENARIO}

The study scenarios were the six Specialized Assistance Services (SAE - Serviços de Assistência Especializada) of the State of Paraíba in activity during the data collection period. People living with HIV from all municipalities in Paraíba are in regular follow up in these services.

\section{SELECTION CRITERIA AND SAMPLE DEFINITION}

The sample was obtained intentionally and included people with a late or very late diagnosis of HIV infection. Sample size was determined by the technique of theoretical saturation or redundancy of information ${ }^{(15)}$. The final sample comprised 18 interviewees. Inclusion criteria were: people with HIV, above 18 years of age on antiretroviral therapy (ART), with late or very late diagnosis, who participated in the quantitative study (previous phase of the study), provided a landline number or a mobile phone number and gave their consent for further contact with the researcher.

\section{Data COllection}

The data collection period was year 2017. An open or unstructured interview was used and the script was prepared by the study authors with a central question regarding the participant's trajectory of life until the HIV diagnosis. The initial procedure was the identification of PLHIV diagnosed late $\left(\mathrm{LT}-\mathrm{CD} 4>=200\right.$ cells $/ \mathrm{mm}^{3}$ and $<350 \mathrm{cells} / \mathrm{mm}^{3}$ ) or very late $\left(\mathrm{LT}-\mathrm{CD} 4<200 \mathrm{cells} / \mathrm{mm}^{3}\right)$, and this information was obtained in the medical record regarding the LT-CD4+ count at the time of diagnosis ${ }^{(1-2)}$. Then, telephone contact was made with people who provided their number in the 
first phase of the study (quantitative axis) and who lived in the metropolitan region of João Pessoa, the state capital, because the region concentrated around $80 \%$ of the total sample of the study.

From the verbal agreement of people contacted to participate in the study, were arranged the days, times and locations for each interview according to participants' preferences. The sites were their residences or the SAE where they were in follow up treatment. The interviewees' privacy was ensured and they signed a written consent. The interviews were recorded with participants' authorization and later transcribed by the researcher. Transcripts were validated through peer review.

\section{ANALYSIS AND PROCESSING OF DATA}

For data analysis, was used the method of Structural Analysis of Narration $^{(16)}$, implemented with support of the MAXQDA $12^{\circledast}$ software that performs the main functions of text organization and codification of empirical material. In the validation process of the coding in MAXQDA, was performed a peer review by using as parameters the percentage of correlation between the coded textual segments corresponding to $80 \%$ and the Kappa index acceptable from $75 \%$.

The analysis of interviewees' narratives revealed representations about the HIV/AIDS object, which were organized according to the expression of density, and importance for participants in original and peripheral representations. Original representations are those expressed in individuals' discourses according to a chronological plan that refers to the initial representations of HIV identified in the social discourse, in a more lasting perspective as a nucleus of permanence and grounding, and by which are identified the stereotypes of sociological objects ${ }^{(11)}$. Peripheral representations are related to subjects' daily experiences, are more flexible to changes and reveal contradictions that may or may not be confirmed along their life trajectories, and may contribute to the confirmation or undermining of the original representations.

\section{ETHICAL ASPECTS}

In compliance with Resolution number 466/2012 of the National Health Council, the study was submitted to the Research Ethics Committee and approved under Opinion numbers 1.870.281 (UFMG), 1.932.530 (UFPB - HULW) and 1.973.626 (UFCG - HUAC). The participation of interviewees was supported by the Informed Consent form. In order to guarantee the anonymity of participants, they were named E1, E2 and so on, according to the sequence of interviews.

\section{RESULTS}

Eighteen people participated in the study. All participants were diagnosed late $(16.7 \%)$ or very late $(83.3 \%)$. Of the total number of interviewees, $50.0 \%$ were male and $50.0 \%$ female; $61.1 \%$ were adults at the time of diagnosis, in the age group of 25 to 49 years; $50.0 \%$ were married or in stable union during the diagnosis period; $50.0 \%$ had
12 years or more of study, as opposed to $33.3 \%$ of those with low schooling (from 1 to 8 years of study); 72.2\% declared themselves to be heterosexual, and most participants (66.6\%) acquired HIV through sexual intercourse with men.

The analysis of interviewees' narratives revealed the following original or central representations: AIDS as a transmissible and dangerous disease; AIDS as the disease of the other, characterized as a person of 'promiscuous' lifestyle with multiple sexual partners; the denial of risk due to trust in a steady partner; AIDS as a serious, incurable and deadly disease.

\section{AIDS IS A TRANSMISSIBLE AND DANGEROUS DISEASE}

The original representation of AIDS as a transmissible disease, either through continuous physical contact, objects of common use, or through respiratory contact, among others, was presented by participants as a basis for the fear of becoming infected and hostility towards seropositive people. Recognition of the high transmissibility potential of the virus associated with the founding myth of HIV infection as a dangerous disease that requires distance from infected people exists in subjects' life trajectories long before they discovered they had the virus.

Oh, I felt so scared when I saw people. I thought I would get it right away, just with the person talking (...) (E10).

On TV, they said it was dangerous, a contagious disease (...) (E18).

Linked to the central idea of a dangerous disease, the narratives reveal the preponderant representation of HIV as a sexually transmitted disease, but there is also the representation of transmission through the air.

(...) I thought I got it like that, in the air, I did not think it was through sexual intercourse. Then, there, today I live this (...). I did not know, I was not aware of (how) you get the disease (...) (E1).

\section{(...) We knew it, we knew it was through sexual intercourse (E2).}

Although participants in this study were aware of HIV transmission through unprotected sex, they did not perceive themselves at risk, even if having intercourse with their partners without a condom.

(...) But it was the matter of not being cautious with people I had a relationship with (...)... It's the matter of trust. (...). Then, I did not believe it! Then, tons of things came into my head, everything I've been through, because of people I already knew, that I lived with, with whom I related, the lack of safety, really, because of trust (E5).

The central representation of risk denial emerging from the reports was sustained by a position of detachment from the object, in spite of the frequent practice of unprotected sex. This distance was mainly due to the feeling of trust in relationships with a steady partner or official marriage. The attitude of trust is anchored in the ideas that the other - partner - is faithful, respects the relationship, alluding to the romantic sense of love, and has a 'clean'body, that is, not contaminated with a virus that is historically related to the stereotype of 'promiscuous' people with a 'dirty' body. 
(...) 'Cause we should not trust everyone, right? Going out with a person and without knowing better... (...). We trust because you look and say: "So-and-so does not have this disease, no, because he is an acquaintance". That's where we get screwed up (...) (E3).

(...) Because you live with a person, you trust a lot. (...) You will not imagine that person will get something like that and will give it to you. Never! Because you trust too much (E18).

From this perspective, the idealized being, the partner, is legitimized by the feeling of trust and by the belief that the other is special, 'perfect' and incapable of doing harm, including 'incapable' of transmitting the 'evil' represented by HIV.

The narratives show the association of the distancing position regarding HIV and the feeling of invulnerability. Therefore, is adopted the practice of unprotected sex, and denial of the risk of infection.

(...) And there were even comments (about the risk, because it was sexual contact), even seen as a joke (...). But I never cared, really (E2).

People used to tell me it was in the relationship, but that couldn't get into my mind. Now, after I caught it, I faced the reality, the real thing (...). I thought it was even a lie (E4).

The representation of the partner as someone free from HIV infection is related to the representation of oneself as a person with a clean body, invulnerable to the risk of contamination and with a single steady partner. The fact of denying the risk leads to inertia in the face of the problem and, consequently, the non-performance of preventive practices, which favors one's contamination and the delayed search for the health service.

\section{AIDS IS THE DISEASE OF THE OTHER}

The representation of oneself refers to the original representation of AIDS as a disease of the other. Participants' discourses revealed who was this 'other', and that HIV infection was not an object that permeated their thoughts. It was characterized as something that could only happen with other people, what makes the feeling of invulnerability evident once again.

(...) This story of HIV never crossed my mind, back in 1997, right? (...). At that time, I heard about Cazuza, right? About that Sandra Bréa too, but it never crossed my mind that it could reach me. It could be with some famous singers, they could take drugs ... I used to think that way, you know? (...) (E4).

Because this is something that happens to others, but it never happens to us (E16).

Inherent in this central idea of AIDS as a disease of the other, is identified the founding myth of the risk group. In essence, this discriminates the self, not susceptible to HIV, from the other, who is exposed to the risks of infection. In this study, this other is characterized as somebody with a 'promiscuous' lifestyle, which is defined as the way of living life, especially men who have sex with men (MSM) and sex workers:

(...) I thought it was more who? People such as homosexuals, women, people who live off the night. I thought it was more these people, who were at greater risk. As I lived at home with my husband, I did not think so (...) (E7).

(...) Usually, we saw that it was more with homosexuals, you know? Those that caught these things. Also women who live with all kinds of men would catch it (...) (E12).

In addition to identifying this other person that is vulnerable to HIV as a person with 'promiscuous' lifestyle, there is an intrinsic representation of risky behavior. However, in discourses, this concept of risk behavior is close to the concept of risk group, since the first expression is used with the meaning of an individual with multiple partners, and not as any subject that has sexual intercourse unprotected.

Promiscuous people (seropositive people). The worst possible people (...) So, I did not consider myself as person engaged in risky behavior. I had friends who went to nightclubs, steam rooms, all these things ... So, for me, this was something for exposed people (E13).

\section{AIDS IS A SERIOUS AND INCURABLE DISEASE}

Based on interviewees' narratives, the original representation of HIV as a serious and incurable disease was revealed without considering the difference between seropositivity and syndrome, which is characterized as the advanced stage of the disease.

The most horrible things in the world, right? It is an incurable disease, one dies from it, people used to say there wasn't even a treatment for it (E11).

What I did not know before I became infected, was the difference between HIV and AIDS (E17).

This indifferentiation of the represented object contributes to the fact of the infected person only searching the health service in the presence of symptoms. Even in the illness process, usually there is no relation of the illness with the possibility of diagnosis of HIV infection, this judgement is not made by the subject or only made as a last alternative. Then, when you find out, it's already late! (...) I almost died. It was just that I did not know what was happening to me (E3).

If I had found out sooner, I would not have got to this point. I thought I was going to die! (E10).

In their imaginary before the diagnosis, interviewees kept the representation of AIDS as a serious, debilitating and incurable disease, in spite of advances in antiretroviral therapy, which increased the quality of life of PLHIV, and the configuration of chronicity related to HIV infection.

As a peripheral representation linked to the representation of AIDS as a serious disease, there is the stereotype of the extremely thin person that confirms the image of a debilitating disease. This representation used to be in interviewees' abstract plane, and was legitimized to pass to their concrete plane of experiences when they were diagnosed late and, therefore, with the advanced disease.

I was scared to see those more advanced cases, when I saw that person who was already weakened, debilitated ... Severe! Precisely because of the issue of healing (E5). 
I was already very bad, a lot of fever, I was very thin, had no appetite (...) (E9).

\section{AIDS IS A DEADLY DISEASE}

Most participants also represented AIDS with the meaning of death, ineluctable and rapid. Despite the advances in the fight against the epidemic and the establishment of its chronicity in the country, people still construct their representations about the phenomenon with the sense of fatality and imminent death, as expressed in the following speeches.

It was a death sentence. We only think about this, as if there were no worse things (E2).

Because it was and is seen as a deadly disease, right? That big disease, that very strong thing, which at the time was very, very stigmatized, right? (...) I thought if I found out, I was going to die soon, in a short time (E15).

The representation of AIDS with the analogous meaning of death through psychic mechanisms of appropriation of representation, can lead individuals to avoid thinking about their possible infection by posing it as a problem distant from their reality. Avoiding to think about the HIV object can also be interpreted in the record of fear of death and thus, fear of AIDS.

I used to hear about it, but today I live it. I did not know it was that dangerous. (...) One would catch it, and if catching it, would die soon. Then I would not put it in my head, I would not put it in my head that I would (die), right? (...) (E1).

When Cazuza died, I was in Rio. That was it... I was scared to death (E9).

Distancing from the problem led to (lack of) knowledge about the risks linked to the infection throughout the interviewees' life trajectory. They only sought health care when the disease was very advanced and severe, which reaffirmed the meaning of death linked to AIDS.

\section{Metaphors of AIDS}

Participants of the study gave metaphorical meanings to HIV/AIDS by using terms such as 'horror film' and 'boogeyman':

(...) Twenty years ago, this was a horror film, because it was, to this day there is a lot of discrimination, but not so much as back then. Then, people who discovered to have such a problem thought their days were numbered (...) (E2).

It was a boogeyman. I thought it was the end of life (E16).

These images of HIV infection as 'boogeyman' or 'horror film' refer to the original representations of a serious, incurable and fatal disease, given the meaning of these expressions. These terms connote the idea of something frightening, terrifying, and contribute to an attitude of distance as a reaction of escape, evasion and inhibition as a result of fear.

Other representations that support the idea of death in the experience of living with HIV were expressed by terms such as 'curse', 'calamity', and 'something very monstrous'.
That it was a curse, that it came and exterminated you, and you had no room to say like: "I'll fight this". It was something like, I cannot explain, it was something very monstrous, really monstrous. But nowadays, I know it is not like that (E13).

People used to say it was a calamity, they were frightened. In the past, it was difficult that a person died, but in a certain way, when catching this disease, died slightly (...) (E14).

The representation of HIV as a curse is related to the founding myth of incurable disease, which leads to an imminent death, and to something undeserved that one does not understand why it happened to him/her, and refers to a feeling of guilt. A curse that leads to the extermination of the guilty person with no opportunity to fight. Monster and a calamity are expressions explaining the notion of disgrace, of catastrophe imposed by fate, which is frightening, and alludes once again to the fear of death. Such psychosocial bases often condition the escape or distance from the problem with consequent late diagnosis of HIV infection.

\section{DISCUSSION}

The fear of contracting HIV infection was a striking idea in the narratives. However, this fear of transmission did not cause a confrontational and preventive reaction in interviewees, such as the practice of safe sex, but the attitude of hostility and distance from people infected.

The original representation of danger unveiled in this study was associated with a feeling of fear related to contagion or transmission. In a study conducted with long-distance truck drivers, were also identified notions of danger and risk related to the fear of acquiring the infection and contaminating the family, which strengthens the meaning of AIDS as a moral threat ${ }^{(17)}$. The representation of AIDS as a dangerous disease or the idea of danger related to HIV infection was also evident in other studies ${ }^{(18-19)}$.

The representation of HIV as sexually transmissible has become socially commonplace. Studies demonstrate the existence of this information in societies ${ }^{(18,20)}$. Participants' narratives revealed that experiencing the diagnosis of HIV infection modified the representation of the form of virus transmission. In other words, the interactions with health professionals and the need to learn to live with HIV have approximated the subjects of the scientific knowledge without necessarily abandoning altogether the previous ideas about transmission, in a confusing and lengthy process of rethinking the world. This process begins with distancing from the HIV problem, and in association with the (lack of) knowledge on the object, it may have influenced the non-perception of risks of infection and the failure to adopt primary prevention measures, which led to transmission and late discovery of the disease.

The closeness of the affective-sexual partner coupled with the idea of a single, steady, intimate and reliable partnership led to denying the risk of contracting HIV and thus, the absence of preventive care for protection against the infection. The feeling of trust is related to the idea of romantic love $\mathrm{e}^{(21)}$, which is not liable to error and cannot harm the loved one. Implicit in this meaning of love, is 
the interpretation of HIV transmission as a malicious and intentional action hence, it cannot be practiced by someone who loves and trusts. The trust in relationships with steady partners as a mediator of the attitude of denying the risk of becoming infected with HIV was a result also observed in other studies $^{(17,19-20,22-23)}$.

Having a steady sexual partner is considered a protective factor, and does not encourage condom use, which can increase vulnerability to HIV and other sexually transmitted infections. Married women generally feel protected from infection, since they attribute meanings of fidelity and security to the marriage, but do not consider the possibility of their partners having extramarital affairs. For these women, the relationship with a steady partner represents a lower probability of exposure to risk because of feelings of trust and exclusivity towards their spouses ${ }^{(20)}$.

At the same time, men have sex with their steady and official partners without a condom, because they feel safe in their relationship with the 'woman at home', and also because of the trust, symbolic closeness and affectivity inherent in the family context with its relationships and values $^{(17)}$. For most men, marriage does not necessarily involve monogamous behavior, but there is the conviction that wives are faithful and always monogamous, which may favor the feeling of invulnerability as a reflection of their hegemonic masculinity ${ }^{(19)}$.

An implication of the representation of denial of risk is the delay in performing HIV screening and, consequently, the late diagnosis. The attitude of not realizing the risk is an obstacle to the test ${ }^{(24)}$, while there is also a distinction between the 'self' and the 'other', which in turn clarifies the dichotomy between 'my group', in which there is no risk or danger, and the 'other groups' that are considered as high risk.

The reference of HIV infection related to the lifestyle of celebrities is one of the first stereotypes of AIDS, of the group of risk of drug users and sexually 'promiscuous'. The representation of AIDS as a disease that affects famous people is related to the idea of consequence of 'deviant' behaviors presented by this public. These behaviors are those related to drug abuse, practice of sex with multiple partners and with people of the same sex ${ }^{(25)}$.

The representation of risk groups was strongly built at the beginning of the epidemic, generated stigma, and remained significant in the representation system of participants in this study. The permanence of this representation linked to 'promiscuous' people, MSM, sex workers and drug users has also been identified in other studies ${ }^{(19,22)}$. A study conducted with university students found an association between representations of risk and ideas of carelessness, promiscuity and irresponsibility. Inherent in these representations, is an attitude of condemnation of the practices of those exposed or who have been exposed to the infection, blaming them for their present condition ${ }^{(18)}$.

The aforementioned representations of AIDS as a transmissible, dangerous disease that affects only the other contributed to people's late search for health services because they did not perceive the risks to which they were exposed. This delayed search was corroborated by representations of
AIDS as a serious, incurable and deadly disease, which led individuals to seek services only when they were already sick.

The representation of AIDS as a serious and incurable disease was also mentioned in other studies ${ }^{(19,26)}$. The idea of incurable disease is associated with the certainty that after confirmation of the infection diagnosis, there is no way back, and the life of HIV-positive individuals will be marked by the presence of the disease until their death ${ }^{(19)}$.

The representation of HIV and AIDS as a single object characterized as a severe and debilitating disease, leads to people's lack of planning or practicing secondary prevention actions, such as periodic tracking of the virus in case of unprotected sex. As a consequence, the search for diagnosis in health services is delayed, because it is only performed in the face of illness and aggravation of symptoms.

In another research, most participants only sought health services and did the HIV test because they were already sick. Out of the 31 interviewees who were diagnosed because of their illness, 14 reported symptoms for more than six months before the HIV test ${ }^{(24)}$.

The representation of AIDS as a disease that causes unavoidable death was also found in other studies ${ }^{(18,26-27)}$. The idea of death linked to HIV/AIDS is unrestricted and reaches people of all kinds, which shows how intense is the anchoring of this original representation ${ }^{(19)}$.

Historically, death has been the object of representation of all individuals in their sociocultural and particular contexts of life. Preponderantly, in the various cultures, meanings of intense grief, sadness, mourning, and despair are attributed to death through the permanent loss of the dying being. In many subjects, this can generate an attitude of denial and escape from thoughts about dying.

In recent decades, despite the evolution of sciences in the treatment of diseases, there is a growing fear of death and it remains a taboo ${ }^{(28)}$. Probable reactions to fear are escape, inhibition/paralysis and aggression/struggle, which are ambivalent behaviors common to men and the animal kingdom. In addition to these reactions, human beings have the ability to manage fear with courage and master it ${ }^{(29)}$. Respondents reacted to the fear of AIDS and death before being diagnosed, either by fleeing from danger, or by inhibiting any adaptive resolution related to the threat.

The articulation between AIDS and death was reinforced by fear and by the feeling of impotence in the face of its inevitability, which was manifested by the strong meaning of metaphors forming the nuclear dimension of the representation system ${ }^{(11)}$. Historically, the central dimension of the representation of AIDS as a synonym of inevitable death is an invariant permeating diverse cultures. It appeared at the beginning of the epidemic and remained strongly in the collective imaginary, despite advances in coping with the epidemic and the effectiveness of current antiretroviral treatments ${ }^{(30)}$.

By conceiving HIV infection as a curse or calamity, respondents have given HIV/AIDS a sinister sense, an evil coming from the action of fate and thus a threat beyond their control. A possible conclusion is that there is no introjection of vulnerability to HIV and awareness that the infection 
occurs due to the lack of prevention, by not using a condom. As a result of not perceiving the risks, study participants did not seek HIV screening after exposure situations and thus, were not aware of their HIV infection at an early stage. The lack of perception of individual vulnerability associated with the representation of AIDS as a severe/advanced disease, certainly contributes to the late search for diagnosis.

\section{CONCLUSION}

The late diagnosis of HIV infection is one of the main obstacles for epidemic control and a multifaceted and complex problem. In this study, this phenomenon was analyzed based on the interpretation of representations about HIV constructed throughout the life trajectory of people diagnosed late.

The results showed that representations of AIDS as a transmissible and dangerous disease that affects only the other have favored the late search for diagnosis in health services. People did not perceive the risks to which they were exposed and felt invulnerable. This delayed search was confirmed by representations of AIDS as a serious, incurable and deadly disease, and by the lack of recognition of asymptomatic HIV infection, which led to the search for services only after the onset and worsening of symptoms.

The main consequence of the lack of perception of individual vulnerability is not performing primary and secondary prevention actions, such as the use of condoms in sexual intercourse and the periodic tracking of the virus after exposure situations. Together, these factors contribute to susceptible individuals not discovering their HIV infection early, which results in the late diagnosis.

The results of this study provided a more in-depth knowledge of this serious public health problem, which is the late diagnosis of HIV and therefore, may contribute to the design of new strategies and policies aimed at the timely diagnosis of the infection.

\section{RESUMO}

Objetivo: Analisar as representações construídas por pessoas vivendo com HIV sobre a infecção e sua influência na busca atrasada por diagnóstico. Método: Estudo de abordagem qualitativa, realizada com pessoas que apresentaram diagnóstico tardio da infecção pelo HIV, por meio de entrevista aberta. O referencial teórico utilizado foi a Teoria das Representações Sociais, a partir de abordagem crítica. Para a análise dos dados, utilizou-se do método da Análise Estrutural de Narração e do programa MAXQDA $12{ }^{\varpi}$. Resultados: Participaram do estudo 18 pessoas. Desvelaram-se como representações originais a aids como doença transmissível e perigosa; doença do outro; doença grave, incurável e mortal; e negação do risco devido à confiança em parceria fixa. Essas representações contribuíram para a busca atrasada por diagnóstico, ora devido à atitude de distanciamento das pessoas susceptíveis, ora por não perceberem ou negarem os riscos aos quais estavam expostas em suas trajetórias de vida. Conclusão: A compreensão dos motivos que conduzem as pessoas a descobrirem tardiamente sua soropositividade é imperiosa no atual panorama da epidemia, para que sejam planejadas e implementadas novas estratégias e políticas que visem ao diagnóstico oportuno da infecção.

\section{DESCRITORES}

HIV; Síndrome de Imunodeficiência Adquirida; Diagnóstico Tardio; Enfermagem em Saúde Pública.

\section{RESUMEN}

Objetivo: Analizar las representaciones construidas de personas viviendo con $\mathrm{VIH}$ acerca de la infección y su influencia en la búsqueda retrasada por diagnóstico. Método: Estudio de abordaje cualitativo, llevado a cabo con personas que presentaron diagnóstico tardío de la infección por el VIH, mediante entrevista abierta. El marco de referencia teórico fue la Teoría de las Representaciones Sociales, desde un abordaje crítico. Para el análisis de los datos, se utilizó el método de Análisis Estructural de Narración y del programa MAXQDA $12^{\circledast}$. Resultados: Participaron en el estudio 18 personas. Se desvelaron como representaciones originales el SIDA como enfermedad transmisible y peligrosa; enfermedad del otro; enfermedad severa, incurable y mortal; y negación del riesgo en virtud de la confianza en pareja fija. Dichas representaciones contribuyeron a la búsqueda retrasada por diagnóstico, ora en virtud de la actitud de alejamiento de las personas susceptibles, ora al no percibir o negar los riesgos a los que estaban expuestas en sus trayectorias de vida. Conclusión: La comprensión de los motivos que conducen a las personas a descubrir tardíamente su seropositividad es imperiosa en el actual panorama de la epidemia, a fin de que se planifiquen e implanten nuevas estrategias y políticas que tengan como objetivo el diagnóstico oportuno de la infección.

\section{DESCRIPTORES}

VIH; Síndrome de Inmunodeficiencia Adquirida; Diagnóstico Tardio; Enfermería en Salud Pública.

\section{REFERENCES}

1. Antinori A, Coenen T, Costagiola D, Dedes N, Ellefson M, Gatell J, et al. Late presentation of HIV infection: a consensus definition. HIV Med. 2011;12(1):61-4. DOI: 10.1111/j.1468-1293.2010.00857

2. Grangeiro A, Escuder MM, Menezes PR, Alencar R, Castilho EA. Late entry into HIV Care: Estimated impact on AIDS mortality rates in Brazil, 2003-2006. PLoS One [Internet]. 2011 [cited 2016 Oct 21];6(1) :e14585. Available from: https://www.ncbi.nlm.nih.gov/pmc/ articles/PMC3026775/

3. Oliva J, Díez M, Galindo S, Cevallos C, Izquierdo A, Cereijo J, et al. Predictors of advanced disease and late presentation in new HIV diagnoses reported to the surveillance system in Spain. Gac Sanit. 2014;28(2):116-22. DOI: 10.1016/j.gaceta.2013.06.009

4. Dai S-Y, Liu J-J, Fan Y-G, Shan G-S, Zhang H-B, Li M-Q, et al. Prevalence and factors associated with late HIV diagnosis. J Med Virol. 2015;87(6):970-7. DOI: 10.1002/jmv.24066

5. Boletim Epidemiológico HIV-AIDS. Brasília: Ministério da Saúde, Secretaria de Vigilância em Saúde, Departamento de DST, AIDS e Hepatites Virais. 2015;4(1).

6. Mocroft A, Lundgren JD, Sabin ML, Monforte Ad, Brockmeyer N, Casabona J, et al. Risk factors and outcomes for late presentation for HIV-positive persons in Europe: results from the Collaboration of Observational HIV Epidemiological Research Europe Study (COHERE). PLoS Med [Internet]. 2013 [cited 2017 Oct 01];10(9):e1001510. Available from: https://www.ncbi.nlm.nih.gov/pmc/articles/PMC3796947/ 
7. Op de Coul EL, van Sighem A, Brinkman K, van Benthem BH, van der Ende ME, Geerlings S, et al.; ATHENA National Observational HIV Cohort. Factors associated with presenting late or with advanced HIV disease in the Netherlands, 1996-2014: results from a National Observational Cohort. BMJ Open [Internet]. 2016 [cited 2017 Sep 25];6(1):e009688. Available from: https://www.ncbi.nlm.nih.gov/pmc/ articles/PMC4716151/

8. Trepka MJ, Fennie KP, Sheehan DM, Lutfi K, Maddox L, Lieb S. Late HIV diagnosis: Differences by rural/urban residence, Florida, 20072011. AIDS Patient Care STDS [Internet]. 2014 [cited 2017 Oct 01];28(4):188-97. Available from: https://www.ncbi.nlm.nih.gov/pmc/ articles/PMC3985529/

9. Almeida ANS, Silveira LC, Silva MRF, Araújo MAM, Guimarães TA. Subjectivity and sexuality production in women living with hiv/ aids: a sociopoetic production. Rev Latino Am Enfermagem [Internet]. 2010 [cited 2017 Oct 10];18(2):163-9. Available from: http://www.scielo.br/scielo.php?script=sci_arttext\&pid=S0104-11692010000200004

10. Almeida MRCB, Labronici LM. A trajetória silenciosa de pessoas portadoras do HIV contada pela história oral. Cien Saude Coletiva. 2007;12(1):263-74.

11. Giami A, Veil C. Enfermeiras frente à Aids: representações e condutas, permanência e mudanças. Canoas: Ulbra; 1997.

12. Moscovici S. A psicanálise, sua imagem e seu público. Petrópolis: Vozes; 2012.

13. Flament C. Structure et dynamique des représentations sociales. In: Jodelet D. Les représentations sociales. Paris: PUF; 1989. p. $204-219$.

14. Kaës R. L'appareil psychique groupal. Paris: Dunod; 1976.

15. Fontanella BJB, Ricas J, Turato ER. Amostragem por saturação em pesquisas qualitativas em saúde: contribuições teóricas. Cad Saúde Pública. 2008;24(1):17-27.

16. Demazière D, Dubar C. Analyser les entretiens biographiques. L'exemple des récits d'insertion. Rev Fr Sociol. 1999;40(2):433-36.

17. Magno L, Castellanos MEP. Significados e vulnerabilidade ao HIV/aids entre caminhoneiros de rota longa no Brasil. Rev Saúde Pública. 2016;50:76. DOI: http://dx.doi.org/10.1590/s1518-8787.2016050006185

18. Galinkin AL, Seidl EMF, Barbosa BT, Magalhães RF. Representações sociais acerca da AIDS e percepção de risco da infecção entre estudantes universitários. Tempus Actas Saúde Coletiva [Internet]. 2012 [citado 2017 out. 18];6(3):51-66. Disponível em: http://www.tempusactas.unb.br/index.php/tempus/article/view/1155/1054

19. Sousa LMS, Silva LS, Palmeira AT. Representações sociais de caminhoneiros de rota curta sobre HIV/AIDS. Psicol Soc. 2014;26(2):346-55.

20. Leal NSB, Coêlho AEL. Representações sociais da AIDS para estudantes de psicologia. Fractal [Internet]. 2016 [citado 2017 out. 18];28(1):9-16. Disponível em: http://www.scielo.br/scielo.php?script=sci_arttext\&pid=S1984-02922016000100009

21. Giddens A. A transformação da intimidade: sexualidade, amor e erotismo nas sociedades modernas. $2^{a}$ ed. São Paulo: UNESP; 2011.

22. Bousfield ABS, Camargo BV. Divulgação do conhecimento científico sobre aids e representações sociais. Acta Colomb Psicol. 2011;14(1):31-45.

23. Costa BA, Panarra S, Teixeira E, Palmeira IP, Rodrigues ILA, Ferreira AMR. Vítimas e culpadas: representações sociais sobre mulheres que vivem com HIV. Rev Cuid. 2017;8(3):1887-98.

24. Schwarcz S, Richards TA, Frank H, Wenzel C, Chin Hsu L, Chin C-SJ, et al. Identifying barriers to HIV testing: personal and contextual factors associated with late HIV testing. AIDS Care. 2011;23(7):892-900. DOI : 10.1080/09540121.2010.534436

25. Oltramari LC, Camargo BV. AIDS, relações conjugais e confiança: um estudo sobre representações sociais. Psicol Estud. 2010;15(2):27583.

26. Rodrigues LSA, Paiva MS, Oliveira JF, Nóbrega SM. Vulnerability of women in common-law marriage to becoming infected with HIV/AIDS: a study of social representations. Rev Esc Enferm USP. 2012;46(2):349-55. DOI: http://dx.doi.org/10.1590/S0080-62342012000200012

27. Dantas MS, Abrão FMS, Freitas CMSM, Oliveira DC. Social representations of HIV/AIDS among healthcare professionals in benchmark services. Rev Gaúcha Enferm. 2014;35(4):94-100.

28. Kübler-Ross E. Sobre a morte e o morrer: o que os doentes têm para ensinar a médicos, enfermeiras, religiosos e aos seus próprios parentes. $7^{\text {a }}$ ed. São Paulo: Martins Fontes; 1996.

29. Morin E. Les anti-peurs. Communications. 1993;57:131-9.

30. Mergui A, Giami A. Les représentations de la sexualité chez de jeunes adultes séropostifs. Sexologies. 2014;23(1):8-13. 